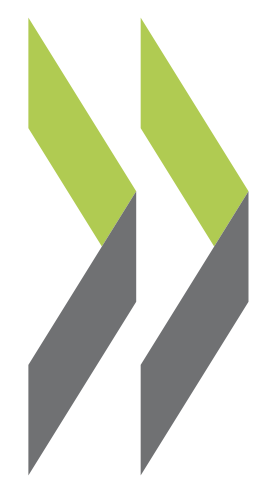

OECD Economics Department Working Papers No. 1360

\title{
Innovation, patent location and tax planning by multinationals
}

Øystein Bieltvedt Skeie,

Asa Johansson,

Carlo Menon,

Stéphane Sorbe 
Organisation de Coopération et de Développement Économiques

Organisation for Economic Co-operation and Development

06-Feb-2017

ECONOMICS DEPARTMENT

English - Or. English

\section{INNOVATION, PATENT LOCATION AND TAX PLANNING BY MULTINATIONALS}

ECONOMICS DEPARTMENTS WORKING PAPERS No. 1360

By Øystein Bieltvedt Skeie, Åsa Johansson, Carlo Menon and Stéphane Sorbe

OECD Working Papers should not be reported as representing the official views of the OECD or of its member countries. The opinions expressed and arguments employed are those of the author(s).

Authorised for publication by Christian Kastrop, Director, Policy Studies Branch, Economics Department.

All Economics Department Working Papers are available at www.oecd.org/eco/workingpapers.

JT03408632

Complete document available on OLIS in its original format

This document and any map included herein are without prejudice to the status of or sovereignty over any territory, to the delimitation of international frontiers and boundaries and to the name of any territory, city or area. 
OECD Working Papers should not be reported as representing the official views of the OECD or of its member countries. The opinions expressed and arguments employed are those of the author(s).

Working Papers describe preliminary results or research in progress by the author(s) and are published to stimulate discussion on a broad range of issues on which the OECD works.

Comments on Working Papers are welcomed, and may be sent to OECD Economics Department, 2 rue André Pascal, 75775 Paris Cedex 16, France, or by e-mail to eco.contact@oecd.org.

All Economics Department Working Papers are available at www.oecd.org/eco/workingpapers.

This document and any map included herein are without prejudice to the status of or sovereignty over any territory, to the delimitation of international frontiers and boundaries and to the name of any territory, city or area.

The statistical data for Israel are supplied by and under the responsibility of the relevant Israeli authorities. The use of such data by the OECD is without prejudice to the status of the Golan Heights, East Jerusalem and Israeli settlements in the West Bank under the terms of international law.

Latvia was not an OECD Member at the time of preparation of this publication. Accordingly, Latvia does not appear in the list of OECD Members and is not included in the zone aggregates.

\section{(C) OECD (2016)}

You can copy, download or print OECD content for your own use, and you can include excerpts from OECD publications, databases and multimedia products in your own documents, presentations, blogs, websites and teaching materials, provided that suitable acknowledgment of OECD as source and copyright owner is given. All requests for commercial use and translation rights should be submitted to rights@oecd.org 


\section{ABSTRACT/RÉSUMÉ \\ Innovation, patent location and tax planning by multinationals}

This paper assesses the effect of international differences in taxes on the choice of patent location by multinational enterprises (MNEs). The analysis is based on a large sample of patents and firms from the OECD-PATSTAT and OECD-ORBIS databases over 2004-10. The approach is to compare the number of patent applications of MNE entities with different links to other countries and thus different sets of location choices, while controlling for other factors affecting patenting behaviour. The results suggest that lower corporate taxes, either in the form of a lower statutory rate or a preferential intellectual property regime, are associated with more patent applications. Both the location of research activities, which is proxied by the location of patent inventors, and the legal ownership of patents are found to be sensitive to corporate taxes. For instance, a 5 percentage point cut in the preferential tax rate on patent income is associated with a $6 \%$ increase in patent applications. On average, about two-thirds of the increase comes from patents invented at home and one third from patents invented abroad, but the relative importance of these two effects is likely to vary with the design of the preferential regime and especially the existence of activity requirements. In addition, strong anti-avoidance measures against tax planning are found to reduce patent shifting by MNEs.

JEL classification codes: F23, $\mathrm{H} 26, \mathrm{O} 34$.

Key words: Corporate taxation, multinational enterprises, tax planning, BEPS, patents, research and development

$* * * * * * * * * * * * * * * * * *$

\section{Innovation, localisation des brevets et planification fiscale des multinationales}

Cet article évalue l'effet des différences internationales d'imposition sur le choix de l'emplacement des brevets par les entreprises multinationales. L'analyse est basée sur un large échantillon de brevets et d'entreprises des bases de données OCDE-PATSTAT et OCDE-ORBIS sur 2004-10. L'approche consiste à comparer le nombre de demandes de brevets d'entités de multinationales ayant différents liens vers d'autres pays et donc différents ensembles de choix de localisation, tout en contrôlant pour les autres facteurs qui influent sur le comportement en matière de brevets. Les résultats suggèrent qu'un niveau plus faible d'impôt sur les sociétés, soit sous la forme d'un taux légal inférieur soit d'un régime de propriété intellectuelle préférentiel, est associé à davantage de demandes de brevets. Tant la localisation des activités de recherche, qui est approchée par le lieu de résidence des inventeurs de brevets, que la propriété juridique des brevets seraient sensibles à l'impôt sur les sociétés. Par exemple, une baisse de 5 points de pourcentage du taux d'imposition préférentiel sur le revenu de brevet est associée à une augmentation de $6 \%$ des demandes de brevet. En moyenne, environ deux tiers de l'augmentation provient de brevets inventés dans le pays en question et un tiers des brevets inventés à l'étranger, mais l'importance relative de ces deux effets est susceptible de varier en fonction de la conception du régime préférentiel et plus particulièrement de l'existence d'exigences de localisation d'activité. En outre, de fortes mesures anti-évitement contre la planification fiscale réduiraient selon les estimations de l'article les transferts de brevets par les multinationales.

Classification JEL: F23, H26, O34.

Mots-clés: Fiscalité des entreprises, entreprises multinationales, planification fiscale, BEPS, brevets, recherche et développement 
TABLE OF CONTENTS

INNOVATION, PATENT LOCATION AND TAX PLANNING BY MULTINATIONALS ......................5

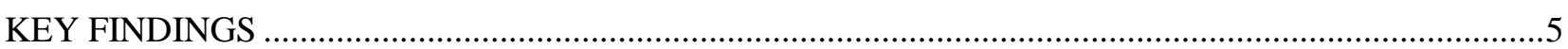

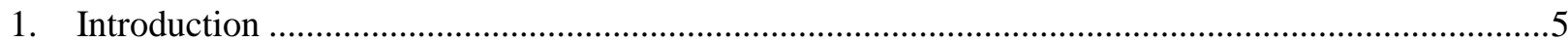

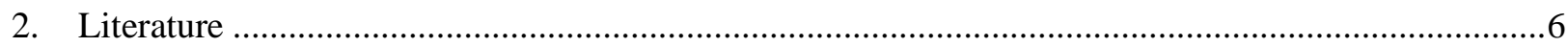

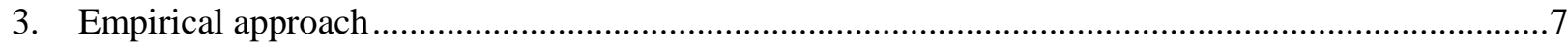

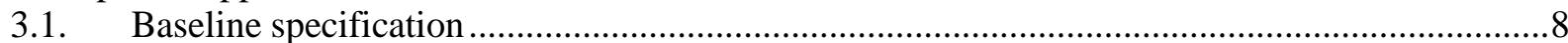

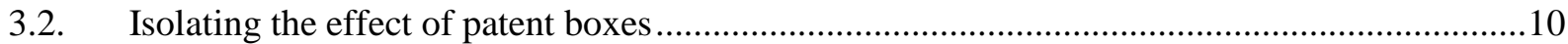

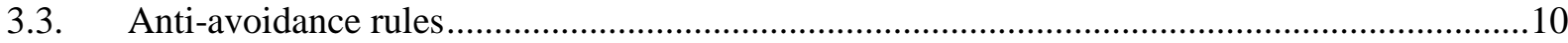

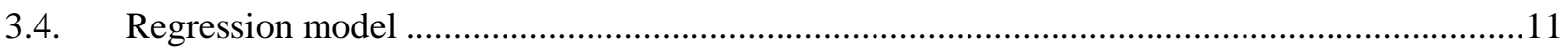

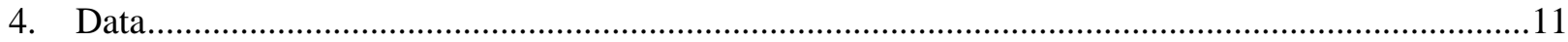

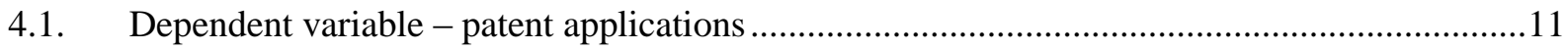

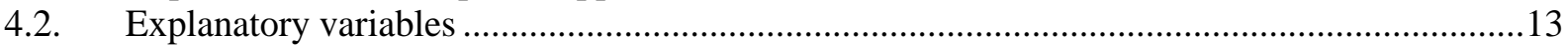

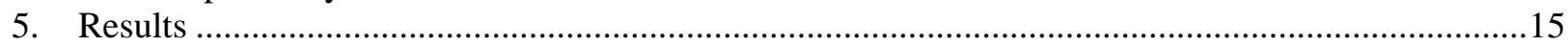

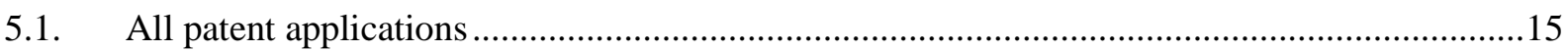

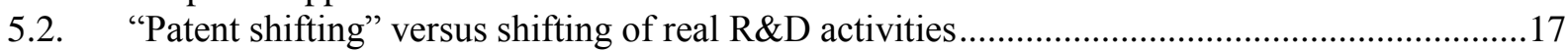

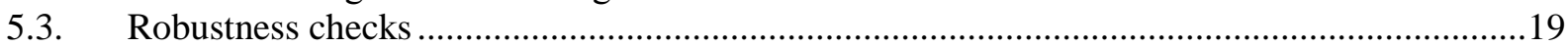

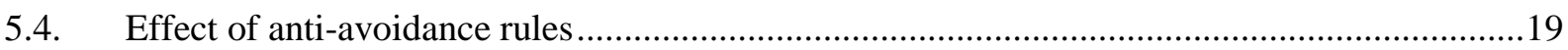

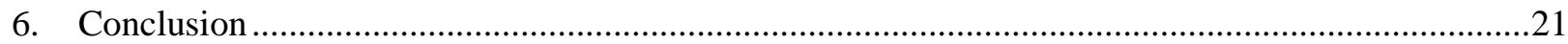

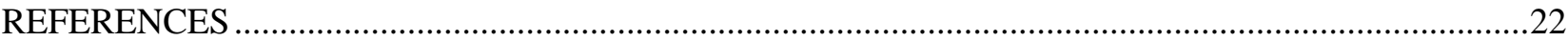

APPENDIX A: LOCATION OF PATENT APPLICATIONS: OLS-SPECIFICATION ............................26

\section{Tables}

Table 1. Number of patent applications per observation in the sample - descriptive statistics ...........12

Table 2. Tax treatment of intellectual property in selected OECD and G20 countries, 2014 ............14

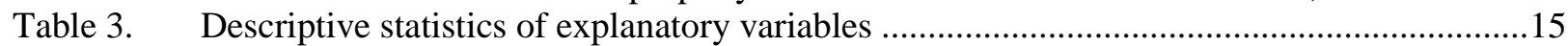

Table 4. Location of patent applications: Non-shifted and shifted patents......................................16

Table 5. Location of patent applications: Anti-avoidance ................................................................20

\section{Figures}

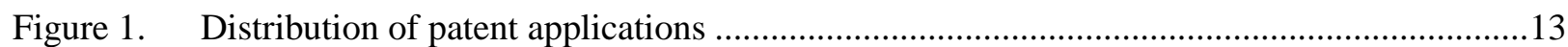

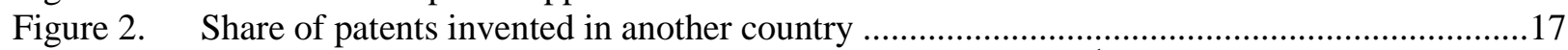

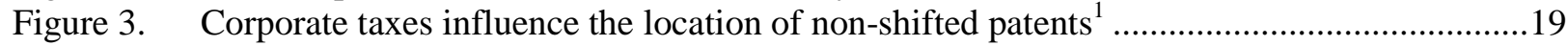


ECO/WKP(2016)84

\title{
INNOVATION, PATENT LOCATION AND TAX PLANNING BY MULTINATIONALS
}

\author{
By Øystein Bieltvedt Skeie, Åsa Johansson, Carlo Menon and Stéphane Sorbe ${ }^{1}$
}

\section{KEY FINDINGS}

- International corporate tax differences and preferential tax treatment of intellectual property influence the location of research activities and the legal ownership of patents.

- Data on the location of patent inventors is used to disentangle the location of research activities from the legal ownership of patents. Corporate taxes are found to influence both the location of research and legal ownership.

- Preferential intellectual property regimes (so-called "IP boxes") attract research activities and the ownership of patents invented in other countries. For instance, a 5 percentage point cut in the preferential tax rate on patent income is associated with a $6 \%$ increase in patent applications. On average, about two-thirds of the increase comes from patents invented at home and one third from patents invented abroad, but the relative importance of these two effects is likely to vary with the design of the preferential regime and especially the existence of activity requirements.

\section{Introduction}

1. The importance of intangible and knowledge-based capital (KBC) for firms' production has grown significantly in recent years (OECD, 2010, 2013a and 2015a). The ability of multinational enterprises (MNEs) and domestic enterprises to increase their market shares, generate profits and improve productivity is increasingly linked to intellectual property (e.g. patents, copyrights, know-how, trademarks, trade names, brands and licences). The location of MNEs' intangible assets depends, among other factors, on corporate taxation. All else equal, countries with lower tax rates or preferential tax regimes for certain investments may attract more R\&D investments than higher-tax countries (CPB, 2014). These investments

1 Øystein B. Skeie (obs@fin.dep.no) worked at the OECD Economics Department when this paper was produced and currently works at the Ministry of Finance in Norway, Asa Johansson (asa.johansson@oecd.org) at the OECD Economics Department, Carlo Menon (carlo.menon@oecd.org) at the OECD Directorate for Science, Technology and Innovation and Stéphane Sorbe (stephane.sorbe@dgtresor.gouv.fr) worked at the OECD Economics Department when this paper was produced and currently works at the French Ministry of Finance. The authors would like to thank Chiara Criscuolo (Directorate for Science, Technology and Innovation), Christian Kastrop, Giuseppe Nicoletti and Jean-Luc Schneider, from the Economics Department, for their valuable comments and suggestions and Sarah Michelson for excellent editorial support (also from the Economics Department). The paper has also benefitted from comments by OECD staff, members of Working Party No. 1 of the OECD Economic Policy Committee and members of Working Party No. 2 of the OECD Committee of Fiscal Affairs. 
can create knowledge spillovers (technological and organisational) from MNEs to domestic firms, with positive effects for aggregate productivity (e.g. Blomström and Kokko, 1998).

2. Reflecting the growing importance of $\mathrm{KBC}$ for production, a number of countries have introduced preferential tax treatment of $R \& D$ and intellectual activities and the income generated by these activities (i.e. "patent boxes" or "IP-boxes"). The design of these regimes differs significantly across countries. In some countries the preferential treatment is conditional on activity requirements and does not apply to acquired intellectual property unless it is further developed in the buying country (PWC, 2013; Evers et al., 2014). Thus, preferential tax treatment may influence both the location of the R\&D investment and of patent legal ownership and income. In some cases, it may also encourage the re-labelling of certain activities or incomes to benefit from the preferential treatment.

3. The growing role of KBC in the economy poses challenges to tax authorities as MNEs can shift profits by locating these assets and associated incomes in lower-tax countries (OECD, 2013b). Profit shifting is facilitated by the fact that intellectual property is difficult to value as there is often no unrelated third-party transaction with similar characteristics to inform the transfer price (i.e. so-called "arm's length" price). As a result, intellectual assets are more susceptible to transfer price manipulation than other assets. This asymmetric information between MNEs and tax authorities creates significant tax planning opportunities for MNEs (Silberztein, 2011).

4. Most countries have introduced "anti-avoidance" rules to restrict tax planning possibilities of MNEs. Among other things, these rules may prevent shifting of patents to reduce taxable profits. Common rules relevant to patent-shifting are rules that hinder the manipulation of the price of transactions between related firms (transfer-pricing rules). Withholding taxes on royalties, as they reduce the income of the firm in the receiving country, can also reduce patent shifting incentives. This paper empirically explores the impact of statutory corporate tax rates and preferential tax treatment of patents on the location of both the legal ownership of patents and the location of the underlying R\&D that results in patents. The paper also explores whether anti-avoidance rules can mitigate tax planning by reducing patent shifting of MNEs.

5. The results suggest that lower corporate taxes, either in the form of a lower statutory rate or a preferential intellectual property regime (so-called "IP box"), are associated with more patent applications. Both the location of research activities, which is proxied by the location of patent inventors, and the legal ownership of patents are found to be sensitive to corporate taxes. For instance, a 5 percentage point cut in the preferential tax rate on patent income is associated with a $6 \%$ increase in patent applications. On average, about two-thirds of the increase comes from patents invented at home and one third from patents invented abroad. However, the relative importance of these two effects is likely to vary with the design of the preferential regime and especially the existence of activity requirements. In addition, the analysis suggests that anti-avoidance rules against tax planning can reduce the potential for tax-motivated patent shifting.

6. The rest of this paper is organised as follows. Section 2 gives a short literature review and describes the contributions of this paper to the literature. Section 3 describes the empirical methodology. Section 4 presents the data. The results are presented in Section 5 while Section 6 concludes.

\section{Literature}

7. This paper relates to the existing literature on tax planning as well as R\&D and patent location. There is broad empirical evidence of profit shifting by multinationals (see e.g. Dharmapala (2014) for a review). Locating intangible assets and the associated royalties in a low-tax country is found to be an important way to shift profits to these countries. Intangible assets can facilitate profit shifting because they are highly mobile and their price is difficult to benchmark to market prices (Grubert, 2003). Furthermore, companies in IP-intensive industries (e.g. computer and electronic components; pharmaceuticals) are more 
likely to be involved in international tax-planning activities. For instance, Johansson et al. (2016a) found that the tax sensitivity of profit is almost twice as high among patenting MNE groups as among nonpatenting ones. A number of studies also show that strong anti-avoidance rules are associated with reduced profit shifting (e.g. Buettner et al., 2012; Johansson et al. (2016a) and Sorbe et al., 2016).

8. Prior literature finds a significant influence of corporate taxation on the location of patents, intangible assets, and R\&D investment. A negative relationship between the corporate income tax rate and the amounts of a firm's intangible assets has been documented by Dischinger and Riedel (2011). A negative effect of the corporate income tax rate on the number of patents were found by Ernst and Spengel (2011); Karkinsky and Riedel (2012); Böhm et al. (2012); Ernst et al. (2014) and Griffith et al. (2014). Furthermore, some studies account for the preferential tax treatment of royalty income (e.g. patent boxes) and find a significant effect (Karkinsky and Riedel (2012); Ernst et al. (2014); Griffith et al. (2014) and Alstadsæter et al. (2015)). This paper is also related to the relatively large literature evaluating the effects of public R\&D subsidy programs on firms' R\&D investment. The early literature is surveyed in Hall and van Reenen (2000) while Mairesse and Mohnen (2010) and Castellacci and Lie (2015) give an overview of later contributions. The latter meta-study found that $R \& D$ tax credits generally enhance $R \& D$, but the effect varies and is on average stronger for SMEs, firms in the service sectors and firms in low-tech sectors.

9. The main contribution of this paper is to assess the effect of corporate taxes (both statutory rate and preferential treatment) on the location of patents over a large sample of MNEs and to disentangle between R\&D location and "patent shifting". More specifically, the identification strategy, inspired by Huizinga and Laeven (2008) and Griffith et al. (2014), is to compare patent applications of MNE entities with similar characteristics except for their link to countries with different tax rates. Both statutory and preferential corporate tax rates are considered. The hypothesis is that MNEs with links to lower-tax countries would apply for fewer patents in entities located in higher-tax countries as compared with similar firms that have no such links. The paper uses information on the location of a patent inventor as a proxy for the location of the $R \& D$ investment underlying the patented innovation, while the location of the ownership is proxied by the country of the MNE entity applying for the patent (i.e. the applicant or socalled assignee). The paper separates between patents where the inventor and applicant are located in the same country ("non-shifted" patents) and patents where they are located in different countries ("shifted" patents). In a second step, the paper isolates the impact of preferential tax treatment. In a third step, the effect of anti-avoidance measures on patent applications is assessed.

10. This paper improves on the existing literature by (i) covering a large sample of patenting firms in both European and non-European countries (including the United States, Japan and Canada), which account for a large share of patent applications to the major patent offices; (ii) relying on a sophisticated algorithm to link firms together into MNE groups developed and described in detail in Johansson et al. (2016a) and Menon (2016); this allows for considering the effect of taxes on the location of patents within the entire MNE group and not only between a parent and an affiliate and (iii) using the information on the location of both the inventors and patent applicants to disentangle the effect of taxes on the location of research activities from the shifting of the ownership of patents invented in another countryand (iv) assesses the effectiveness of anti-avoidance measures against patent shifting behaviours.

\section{Empirical approach}

11. MNEs make several decisions regarding where to locate their R\&D activities and the output of their research. First, a MNE has to decide where to locate the R\&D activity and second where to (initially) locate the legal ownership to the invention. In this analysis, the location of the R\&D activity is not directly observed and the location of patent inventors is used as a proxy. The analysis distinguishes between patent applications where the inventor is located in the same country as the firm applying for the patent protection and those where the country of the inventor and applicant differ. In general, the country of residence of the 
applicant determines the tax liability on patent income. When the location of the inventor and the applicant is the same, the effect of taxes is expected to reflect the tax sensitivity of the location of R\&D. ${ }^{2}$ By contrast, when locations differ, the patent is owned in a different country from where it was invented, possibly for tax reasons. Non-tax reasons may also play a role. For example, MNEs may want to concentrate ownership of patents at the headquarters level (e.g. for practical reasons) regardless of where the innovative activity occurred. ${ }^{3}$

12. Patent data include detailed information on individual patents' inventor(s) (name and address) and applicant(s) (name and address). Thus, it is possible to identify in which country the patent is invented and in which country the initial ownership of the patent is located, even though cases of multiples inventors or applicants complicate this identification. When these two countries are the same, it is assumed that the MNE has not shifted the ownership of the patent (non-shifted patents). When they differ, it is assumed that the legal ownership of the patent has been shifted (shifted patents). The empirical analysis is conducted for three sub-samples of patent applications: all patents, non-shifted patents and shifted patents.

\subsection{Baseline specification}

13. The empirical approach to assess tax sensitivity of patent location is to compare the patent applications of MNE entities with similar characteristics except for their link to countries with different tax rates. The hypothesis is that MNEs with links to lower-tax countries would apply for relative fewer patents in entities located in higher-tax countries compared with other similar firms that have no such links. In practice, the baseline equation is as follows:

(1) Patents $f, g, i, c, t$

$$
\begin{aligned}
& =f\left\{\left(\text { EffectiveTaxPatent }_{c, t}-\text { EffectiveTaxPatent_group_avg }_{g, i, c, t}\right),\left(S T A T_{c, t}\right.\right. \\
& \text {-STAT_group_avg } \left.\left.g_{g, i, c, t}\right), X_{f, g, i, c, t}, Y_{g, i, c, t}, Z_{c, t}, \delta_{i}, \delta_{c}, \delta_{t}, \varepsilon_{f, g, i, c, t}\right\}
\end{aligned}
$$

where Patents $_{f, g, i, c, t}$ is the number of patent applications of firm $f$ (belonging to MNE group $g$ operating in industry $i$ and country $c)$ in year $t$. (EffectiveTaxPatent ${ }_{c, t}-$ EffectiveTaxPatent_group_avg $\left._{g, i, c, t}\right)$ is the difference between the effective tax rate on patent income in country $c$ and the (unweighted) average effective tax rate on patent income in the countries where the MNE group $g$ operates. The effective tax rate on patent income is the patent-box tax rate if a patent box exists; otherwise it is the statutory corporate tax rate. In addition, taxes may have an indirect effect through their effect on investment. Indeed, a lower statutory tax rate is generally expected to increase investment (Arnold et al., 2011; Sorbe and Johansson, 2016). Some of the additional investment may generate positive spillovers to R\&D activities and ultimately on patenting. To separate the direct effect of the effective tax rate on patent income from this indirect effect of the statutory tax rate, the difference between the statutory tax rate in the home country and the average statutory tax rate in the group, $\left(S T A T_{c, t}-S T A T_{\_} g r o u p_{\_} a v g_{g, i, c, t}\right)$, is included as a control variable.

14. $X_{f, g, i, c, t}, Y_{g, i, c, t}$ and $Z_{c, t}$ are vectors of control variables, including: the entity's lagged stock of patent applications, the concentration of researchers (defined in differential terms relatively to the MNE group average, in the same way as the tax rate variables), dummies for firm size categories, position in the MNE group (headquarters, other parent entity or non-parent entity), size of the MNE group (proxied by the

2. Inventors might also choose their own location in response to taxes, especially to the personal income tax (Akcigit et al., 2015).

3. To control for this effect the empirical specification controls for the position in the group, i.e. whether the entity is the group headquarters, another parent entity or a non-parent entity. 
number of countries where it operates), $R \& D$ tax subsidies at home and on average in the countries where the group operates. $\delta_{i}, \delta_{c}$ and $\delta_{t}$ are industry, country and time fixed-effects. $\varepsilon_{f, g, i, c, t}$ is the error term. The equation is estimated using a negative binomial model, which is a non-linear model suited for highvariance count data such as patent numbers.

15. The difference between the effective tax rate at home and the unweighted average in the group takes into account the tax rate and preferential treatment in all countries where the MNE group is identified as operating, including countries outside the estimation sample. This allows for considering the effect of tax differentials on the location of patent applications within the entire MNE group and not only between a parent and an affiliate, which is an improvement over existing papers. The effect of the effective tax rate difference is expected to be negative. The effect of the statutory tax rate difference is also expected to be negative. Relying on an unweighted average of tax rates, as done in this paper, does not reflect the "weight" of the different countries in the group structure. However, there is no appropriate weighting strategy, since weights based on activity levels (e.g. sales or employment) may not reflect profit shifting possibilities (profit can be shifted even to locations where the group has little activity) and weights based on profits, as used by Huizinga and Laeven (2008), can pose endogeneity issues.

16. One important control variable is the lagged depreciated stock of patent applications. Innovating firms build knowledge in how to innovate. Thus, firms that have innovated in the past are more likely to innovate in the future relative to other firms. The permanent capacities of firms to innovate are reflected in the pre-sample history of innovative success. Following Blundell et al. (1995), the specification controls for the "entry stock" (i.e. lagged stock) of patents to take into account differences in firms' innovative capacity.

17. MNEs likely locate their R\&D activities in locations with a good supply of researchers. Thus, it is important to control for the concentration of researchers in different countries. Similarly to the tax variable, the researcher variable is constructed as the difference between the concentration of researchers (i.e. number of researchers per inhabitant) in the country where the entity is located and the average (unweighted) concentration of researchers of countries represented in the MNE group. A positive value, i.e. higher concentration of researchers at home than in the average of the group, is expected to have a positive effect on patent applications.

18. Multinationals sometimes concentrate their ownership of assets including patents at the level of headquarters or in other companies located towards the top of the group structure. To control for such effects, dummies for group headquarters and other parent entities (as opposed to non-parent entities, which are at the bottom of the corporate structure) are included.

19. R\&D tax subsidies exist in several OECD and non-OECD countries to encourage firms to invest in R\&D. Tax subsidies can help attract the location of MNEs R\&D facilities (Criscuolo et al., 2009). They can also have a positive effect on patent numbers (Westmore, 2013). In addition, there could be a positive or negative effect of tax subsidies abroad on patenting at home via positive knowledge spillovers and negative displacement effects. To account for these effects, the average $R \& D$ tax subsidy of countries in which the MNE group operates is included as an additional control. The generosity of R\&D tax subsidies is measured by the tax subsidy rate, which is defined as the before-tax income needed by a "representative" firm to break even on one dollar of R\&D outlays (Warda, 2001). To take into account that an innovation process normally takes some time, the R\&D tax subsidy rate at home and abroad is lagged by three years.

20. Large firms are expected to apply for more patents than smaller firms. To control for this effect, entity size dummies are included. In addition, it is likely that there are knowledge spillovers between entities within the same group. Entities that are part of larger MNE group are expected to have more patents than entities in smaller groups. To control for this effect, the number of countries represented in the 
MNE group is used as a proxy for the size of the group, since other potential indicators (e.g. assets, employment) are not always available at the group-wide level.

21. An important caveat to the analysis is that the possible transfer of ownership of granted patents is not covered. When a patent is granted by the patent office, the owner of the patent can sell the patent to external or related parties without having to notify or register the transfer of ownership. Transferring ownership of existing patents to related parties can be used for tax planning purposes and such transfers are not covered by the analysis due to lack of cross-country administrative data on transfer of patent ownership. However, this is mitigated by the fact that when MNEs make the initial location decision they consider taxes since there are tax costs of transferring patent ownership since such transactions are subject to transfer pricing rules (Griffith et al., 2014).

22. Another caveat is that MNEs can in certain cases attribute income from intellectual property to low-tax jurisdictions even though the legal ownership to the property is held in a higher-tax country. This can occur through business arrangements which are set up to share the costs and risks of developing intellectual property (so-called "cost contribution arrangements"). The use of such arrangements is not covered in this analysis due to lack of data. The findings in this paper are thus a lower bound of the effect of taxes (including preferential tax treatment of patents) on MNEs' location of patent ownership and related income.

\subsection{Isolating the effect of patent boxes}

23. To isolate the effect of patent boxes, the effective tax rate is interacted with a dummy variable $\left(\right.$ PatentBoxdummy $\left.y_{c, t}\right)$ identifying whether the country has a patent box or not. The effect of the effective tax rate differential is expected to be negative both in countries with a patent box and in countries without a patent box, but magnitudes may differ. The other control variables are as in specification (1).

\subsection{Anti-avoidance rules}

24. Most countries have introduced "anti-avoidance" rules to restrict tax planning possibilities of MNEs. Among other things, these rules may prevent shifting of patents to reduce taxable profits. Common rules relevant to patent-shifting are rules that hinder the manipulation of the price of transactions between related firms (transfer-pricing rules). Withholding taxes on royalties, as they reduce the income of the firm in the receiving country, can also reduce patent shifting incentives.

25. The empirical framework needs to be slightly adapted to test whether anti-avoidance rules influence the location of patents. Indeed, the effect of these rules is not symmetric (Johansson et al., 2016a). They are, for example, designed to prevent shifting of patents out of a country, but they generally do not prevent shifting of patents into a country. To account for this asymmetry, the sample is split into two parts: firms facing a higher effective tax rate on patents than the average in their group (which have incentives to shift patents to lower-tax entities) and firms facing a lower tax rate than this average (which are more likely to receive shifted patents). The effectiveness of anti-avoidance rules is tested only on the first group. The hypothesis is that the tax sensitivity of patents of these firms would be lower in countries with strict anti-avoidance rules, as the possibility and financial incentive to shift patents would be reduced. More specifically, the estimated equation is the following: 
(2) Patents $f, \mathrm{~g}, i, c, t$

$$
\begin{aligned}
& =f\left\{\left(\text { EffectiveTaxPatent }_{c, t}\right.\right. \\
& \text { - EffectiveTaxPatent_group_avg } \left.g_{g, i, c, t}\right)_{\text {when positive }}\left(\text { EffectiveTaxPatent }_{c, t}\right. \\
& \text { - EffectiveTaxPatent_group_avg } \left.g_{g, i, c, t}\right)_{\text {when negative }}\left(\text { EffectiveTaxPatent }_{c, t}\right. \\
& \text { - EffectiveTaxPatent_group_avg } \left.g_{g, i, c, t}\right)_{\text {when positive }} \\
& \left.\times A S_{c, t},\left(S T A T_{c, t}-S T A T_{-} g r o u p_{-} a v g_{g, i, c, t}\right), X_{f, g, i, c, t}, Y_{g, i, c, t}, Z_{c, t}, \delta_{i}, \delta_{c}, \delta_{t}, \varepsilon_{f, g, i, c, t}\right\}
\end{aligned}
$$

where $A S_{c, t}$ is a classification of anti-avoidance rules in country $c$ and year $t$. The coefficient of the tax rate differential is expected to be negative (both for positive and negative differentials). The tax rate differential (when positive) interacted with the anti-avoidance classification is expected to be positive. For a given number of inventions, stronger anti-avoidance rules would make it more difficult to shift patents away from the country of the inventor, thus leading to more non-shifted patents than with less strict antiavoidance rules.

\subsection{Regression model}

26. The preferred regression model for patent data is the negative binomial regression model. This is because the dependent variable, which is the annual number of patent applications per firm is overdispersed count data. For count data (i.e. variable taking non-negative integer values $0,1,2$, etc.), the Poisson-model is the standard choice. The Poisson regression model is based on the assumption that the variance of the dependent variable is equal to its mean. This assumption will generally not hold for patent data. Most patenting firms have very few (or no) patent applications per year, while a few firms apply for many patents per year. Thus, the variance is much larger than the mean, i.e. the data is overdispersed, which implies that the assumption of the Poisson-model does not hold. The preferred regression model for such data is instead the negative binominal regression model (Greene, 2003).

27. A common alternative to the negative binominal regression model is to estimate a standard OLSregression on the transformed variable $\log (1+$ patents) (Wooldridge, 2010; Cameron and Trivedi, 2013). This is done as a robustness check (results are presented in Appendix A).

\section{Data}

\subsection{Dependent variable - patent applications}

28. The dependent variable is the annual number of patent applications per MNE entity. Patents considered are patents filed in two major patent offices (i.e. the United States Patent and Trademark Office (USTPO) and the European Patent Office (EPO)) or under the Patent Co-Operation Treaty (PCT). The data source is the OECD patent database. ${ }^{4}$ The OECD Patent database covers bibliographic records on patent applications filed in most Intellectual Property Offices worldwide. The information available covers three main categories: the technical description of the invention (title, technical classes, citations); the ownership of the invention (inventor and applicant/owner); and the history of the application (key administrative dates and the legal steps). The data contained in the OECD Patent database mostly derive from the Worldwide Patent Statistical Database, PATSTAT, maintained by the European Patent Office (EPO).

29. Patent records only contain administrative information on patent applicants. Characterising the applicants as firms to use information on their size, sector and links to other countries therefore requires

4. See http://www.oecd.org/science/inno/oecdpatentdatabases.htm. 
linking patent data to enterprise data from another source. The OECD has done this linking by merging the names of patent applicants available in PATSTAT with the names of firms in the OECD-ORBIS database using the harmonised HAN database (see Andrews et al., 2014; Squicciarini and Dernis, 2013). The OECD-ORBIS is a database based on the commercial database ORBIS provided by Bureau van Dijk containing demographic, structural and financial information of firms located worldwide (Pinto et al., 2010; Ragoussis and Gonnard, 2012).

30. The merged dataset of patents and firm characteristics has been cleaned to ensure consistency. First, following Griffith et al. (2014), the sample only includes MNE entities that patent regularly. MNE entities are kept in the sample if they have filed at least one patent over 2004-10. Second, following Karkinsky and Riedel (2012), entities with a very large number of patent applications in at least one year are dropped from the sample (more specifically, the threshold corresponds to the top $0.5 \%$ of the distribution of the maximum annual number of patents of an entity, i.e. about 500 patents). This is done to avoid results being driven by outliers. The final sample consists of 94,000 MNE entity observations in 26 countries, with about 550,000 patents applications over 2004-10.

31. The empirical analysis is conducted for three sub-samples of patent applications: all patents, nonshifted patents (country of inventor and applicant is the same) and shifted patents (country of inventor and applicant differ). When there are more than one inventor and/or more than one applicant registered for a patent, the country of the first inventor and/or applicant is used.

32. Descriptive statistics of the dependent variables (all, non-shifted and shifted patents) are presented in Table 1 and in Figure 1. The distribution of patent applications in the dataset is clearly skewed to the right with a majority of observations presenting a small number of patent applications (more than $56 \%$ of the observations have no patents in the considered year and more than $12 \%$ of the observations have only one patent). ${ }^{5}$ Indeed, the variance of the number of patent applications is much larger than the mean, which indicates that the dataset in overdispersed and confirms that the negative binominal regression model is appropriate.

Table 1. Number of patent applications per observation in the sample - descriptive statistics

\begin{tabular}{|c|c|c|c|c|c|}
\hline Variable & Obs. & Mean & St.dev. & Min. & Max. \\
\hline All patents & 94,228 & 11.1 & 108.6 & 0 & 8,146 \\
\hline Non-shifted patents & 94,228 & 9.6 & 90.3 & 0 & 5,079 \\
\hline Shifted patents & 94,228 & 1.5 & 28.5 & 0 & 3,752 \\
\hline All patents - dropping the upper $0.5 \%$ & 93,759 & 5.9 & 24.6 & 0 & 490 \\
\hline Non-shifted patents - dropping the upper $0.5 \%$ & 93,759 & 5.2 & 22.3 & 0 & 476 \\
\hline Shifted patents - dropping the upper $0.5 \%$ & 93,759 & 0.7 & 5.5 & 0 & 345 \\
\hline
\end{tabular}

5. There is a very long tail to the right with $1 \%$ of the observations above 179 patent applications per year and $0.1 \%$ of the observations having more than 1,400 patent applications per year. 
Figure 1. Distribution of patent applications

Annual patent applications (all applications)

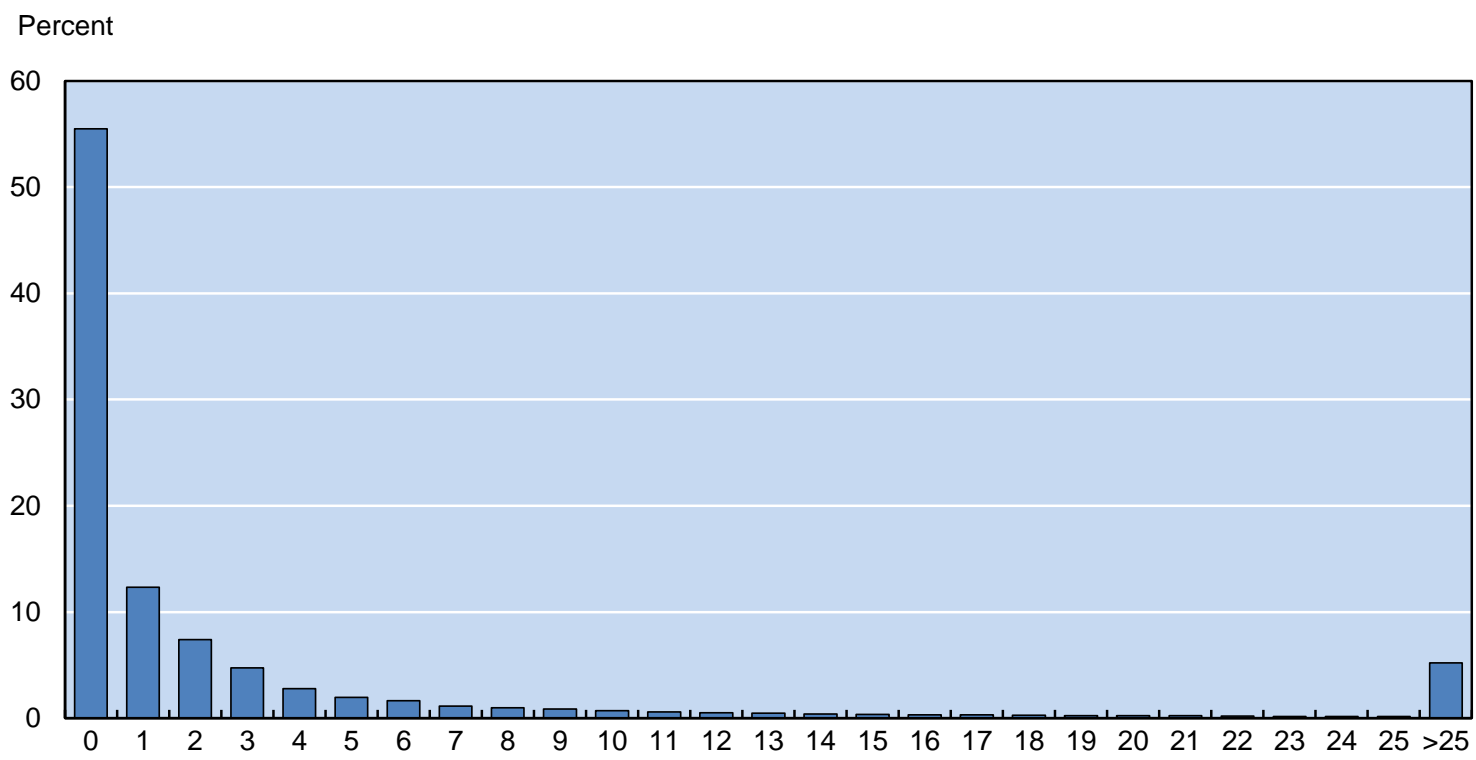

1. The figure shows the distribution of annual patent applications per entity in the sample. $55 \%$ of the observations have 0 patent applications and $12 \%$ of the observations have 1 patent application. $5 \%$ of the observations have above 25 patents per year.

\subsection{Explanatory variables}

33. The main explanatory variables are the tax rate differential between the home country and the average among the other countries where the MNE group has activities. The information on the MNE group (number of countries represented in the group, position in the group, etc.) is sourced from Johansson et al. (2016a) and based on Menon (2016). Two entities are assumed to be linked if one owns the other, directly or indirectly, with an ownership share of at least $50 \%{ }^{6}$ All entities that are linked together are considered to belong to the same corporate group and thus to be possible locations for the patent application. $^{7}$

34. The source of statutory corporate tax rates are the OECD tax database complemented with data from KPMG for non-OECD countries. The information on preferential tax treatment (of patents and other intellectual property is sourced from Evers et al. (2014) and PWC (2013) (Table 2).

6. The rationale for the 50\% threshold is that tax planning and in this case relocation of patents would generally take place between two companies that are under the same control.

7. The ownership structure is sourced from ORBIS and it may be incomplete in some cases (for more details and statistics on ORBIS data coverage, see Johansson et al., 2016a). 
Table 2. Tax treatment of intellectual property in selected OECD and G20 countries, $2014^{1}$

\begin{tabular}{|c|c|c|c|c|c|}
\hline Country & $\begin{array}{l}\text { Corporate } \\
\text { tax rate }\end{array}$ & $\begin{array}{l}\text { Patent box } \\
\text { rate }\end{array}$ & Qualifying intellectual property & $\begin{array}{l}\text { Acquired intellectual } \\
\text { property }\end{array}$ & $\begin{array}{c}\text { Year of } \\
\text { introduction }\end{array}$ \\
\hline Belgium & 34 & 6.8 & Patents, Supplementary Protection Certificates & $\begin{array}{l}\text { Yes, if further } \\
\text { developed }\end{array}$ & 2007 \\
\hline China & 33 & $0-12.5$ & Patents, process innovation & na & 2008 \\
\hline France & 34.4 & 15.5 & $\begin{array}{l}\text { Patents, extended patent certificats, patentable inventions, } \\
\text { manufacturing processes associated w ith patents, } \\
\text { improvements of patents }\end{array}$ & $\begin{array}{l}\text { Yes, under certain } \\
\text { conditions }\end{array}$ & 2001 \\
\hline Hungary & 19 & 9.5 & $\begin{array}{l}\text { Patents, industrial designs, trademarks, copyrights, know - } \\
\text { how, business secrets }\end{array}$ & Yes & 2003 \\
\hline Luxembourg & 29.2 & 5.84 & $\begin{array}{l}\text { Patents, designs, trademarks, brands, domain names } \\
\text { copyrights on softw are }\end{array}$ & Yes & 2008 \\
\hline Netherlands & 25 & 5 & Patents, Intellectual propert from R\&D projects & $\begin{array}{l}\text { Yes, if further } \\
\text { developed }\end{array}$ & 2007 \\
\hline Portugal & 31.5 & $\begin{array}{c}50 \% \text { of } \\
\text { gross } \\
\text { income } \\
\text { exempted }\end{array}$ & $\begin{array}{l}\text { Patents, industrial designs or other protected intellectual } \\
\text { property rights }\end{array}$ & $\begin{array}{l}\text { Yes, if transfer complies } \\
\text { w ith transfer pricing } \\
\text { rules and country not } \\
\text { considered a tax haven }\end{array}$ & 2014 \\
\hline Spain $^{2}$ & 30 & $\begin{array}{c}60 \% \text { of } \\
\text { patent } \\
\text { income } \\
\text { exempted }\end{array}$ & Patents, secret formulas and procedures, plans, models & $\begin{array}{l}\text { Yes, under certain } \\
\text { conditions }\end{array}$ & 2008 \\
\hline $\begin{array}{l}\text { Sw itzerland } \\
\text { (Niedw alden) }\end{array}$ & 21.1 & 8.8 & $\begin{array}{l}\text { Patents, secret formulas and processes, trademarks, } \\
\text { copyrights, softw are, know -how }\end{array}$ & Yes & 2011 \\
\hline $\begin{array}{l}\text { Turkey (Technology } \\
\text { development zones) }\end{array}$ & 20 & 20 & Patents, licences, Intellectual propert from $R \& D$ projects & No & 2001 \\
\hline United Kingdom & 21 & 10 & $\begin{array}{l}\text { Patents, Supplementary Protection Certificates, certain } \\
\text { other rights similar to patents }\end{array}$ & $\begin{array}{l}\text { Yes, if further } \\
\text { developed }\end{array}$ & 2013 \\
\hline
\end{tabular}

1. Existing intellectual property regimes in the OECD and G20 that do not meet the agreed standard for substantial activity should close to new entrants in June 2016 and stop operating in June 2021 (G20 communiqué, February 2015).

2. The corporate rate is reduced to $28 \%$ in 2015 and $25 \%$ in 2016 and onwards.

Source: PWC (2013), Evers et al. (2014) and OECD (2015b)

35. The depreciated stock of patent applications is estimated based on a perpetual inventory method, assuming a constant depreciation rate of $15 \%$ per year for all patent applications since 1970 based on the matched ORBIS PATSTAT data (see Andrews et al., 2014 for details). Data on R\&D personnel is sourced from the OECD Science and Technology Industry Outlook. The R\&D tax subsidy is measured by $1-B$ index taken from the OECD R\&D Tax Incentives Indicators.

36. The size variable is a categorical variable taking values from 1 to 6 where 1 is a micro-firm and 6 is a huge firm. The variable relies on the number of employees (thresholds: 10, 50, 250, 1,000, 10,000 employees). When the number of employees is not available, firm size is defined based on total assets (thresholds: EUR 2m, EUR 10m, EUR 43m, EUR 172m and EUR 1,720m) or turnover (thresholds: EUR 2m, EUR 10m, EUR 50m, EUR 200m and EUR 2,000m).

37. The anti-avoidance classification aims to gauge the strictness of key anti-avoidance rules and withholding taxes. The classification used in the analysis is a sub-indicator of the broader classification compiled in Johansson et al. (2016b), and includes only the components concerning transfer pricing rules and withholding taxes, which are the rules most targeted at tax planning through patent-shifting. As rules are complex and country-specific, the classification inevitably relies on simplifying assumptions. Notably, the classification does not take into account enforcement of existing rules. The analysis relies on values for 2005 and for simplicity assumes no change in the anti-avoidance stance over the estimation period. Table 3 presents descriptive statistics for the explanatory variables. 
ECO/WKP(2016)84

Table 3. Descriptive statistics of explanatory variables

\begin{tabular}{|c|c|c|c|c|c|}
\hline Variable & Obs. & Mean & St.dev. & Min. & Max. \\
\hline $\begin{array}{l}\text { Difference to average effective tax rate on patent } \\
\text { income in the group }\end{array}$ & 93,759 & 0.019 & 0.074 & -0.247 & 0.237 \\
\hline $\begin{array}{l}\text { Difference to average effective tax rate on patent } \\
\text { income in the group, when no patent box at home }\end{array}$ & 93,759 & 0.034 & 0.052 & -0.136 & 0.237 \\
\hline $\begin{array}{l}\text { Difference to average effective tax rate on patent } \\
\text { income in the group, when patent box at home }\end{array}$ & 93,759 & -0.015 & 0.040 & -0.247 & 0.060 \\
\hline $\begin{array}{l}\text { Difference to average statutory tax rate in the } \\
\text { group }\end{array}$ & 93,759 & 0.027 & 0.050 & -0.202 & 0.195 \\
\hline Anti-avoidance classification & 93,720 & 2.14 & 0.77 & 1 & \\
\hline Lagged depreciated stock of patent applications & 93,759 & 27. 1 & 122.9 & 0.0 & $5,905.6$ \\
\hline $\begin{array}{l}\text { Difference to average concentration of researchers } \\
\text { of countries represented in the group }\end{array}$ & 93,759 & 0.978 & 1.776 & -5.919 & 10.148 \\
\hline Headquarter dummy & 93,759 & 0.226 & 0.418 & 0.000 & 1.000 \\
\hline Parent dummy & 93,759 & 0.482 & 0.500 & 0.000 & 1.000 \\
\hline Number of countries in the group & 93,759 & 13.1 & 18.2 & 2.0 & 120.0 \\
\hline Lagged R\&D tax subsidies at home & 93,759 & 0.072 & 0.104 & -0.030 & 0.441 \\
\hline Lagged average $R \& D$ tax subsidies in the group & 93,759 & 0.100 & 0.071 & -0.030 & 0.441 \\
\hline Size & 93,759 & 3.3 & 1.3 & 1.0 & 6.0 \\
\hline
\end{tabular}

\section{Results}

\subsection{All patent applications}

38. The baseline results for all patent applications (shifted and non-shifted) are reported in Table 4 . The baseline regression results show that the effect of taxes on patent applications is negative (column 1), which supports the assumption that MNEs are locating their patents applications in lower tax countries. The estimated coefficient of the effective tax rate on patent income implies that an effective tax rate on patent income (statutory or preferential) above the MNE group average by 1 percentage point is associated with a reduction in patent applications by about $0.9 \%{ }^{8}$ As expected, the statutory tax rate also has a negative effect on patent applications, although the effect is only significant at the $10 \%$ level. The estimated coefficient implies that a statutory tax rate above the group average by 1 percentage point is associated with a reduction in patent applications by about $0.6 \%$.

39. When interacting the effective tax rate on patent income with a patent box dummy (Table 4, column 2), the estimated effect is slightly stronger in countries without than in countries with a patent box, but the difference between the coefficients is not statistically significant.

8. The coefficient estimates in a negative binominal model have no direct quantitative interpretation. To obtain a meaningful interpretation, an incident risk ratio (irr) has to be calculated. This is done by exponentiating the coefficient, $i r r=e^{\text {coeff }}$. A one unit change in the explanatory variable, keeping all other factors constant, will change the dependent variable with a factor equal to the irr (see Cameron and Triveldi, 2013). 
Table 4. Location of patent applications: Non-shifted and shifted patents

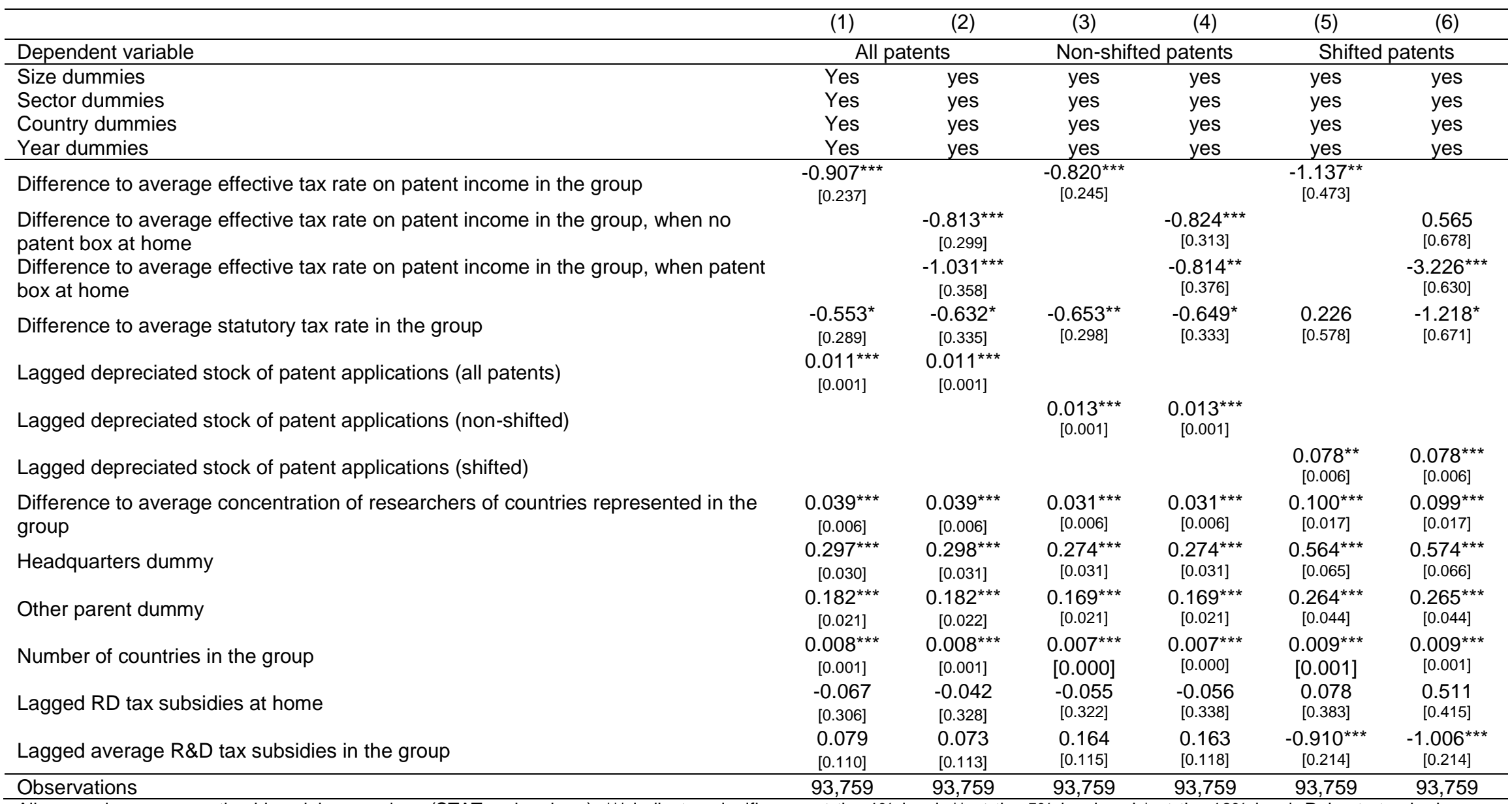

All regressions are negative binomial regressions (STAT-code: nbreg). ${ }^{* * *}$ indicates significance at the $1 \%$ level, ${ }^{* *}$ at the $5 \%$ level and ${ }^{*}$ at the $10 \%$ level. Robust standard errors corrected for clustering at the country-year level are presented under brackets. The dispersion parameter alpha is significantly greater than zero in all specifications, which confirms that the data are overdispersed and are better estimated using a negative binomial model than a poisson model. The sample consists of patenting MNEs in 25 countries over 2004-2010.

Patent data is from the OECD-PATSTAT database. Information on ownership and firm characteristics are taken from OECD-ORBIS database. 
40. The control variables are stable over both specifications (Table 4, column 1-2) and their signs are in line with expectations (see section 2.1). In contrast to Westmore (2013), the regression results show no significant effect of R\&D tax subsidies on the number of patent applications. There may be several reasons for this. $R \& D$ tax subsidies may increase $R \& D$ expenditures, but not necessarily the type of $R \& D$ expenditures which results in patents. This is in line with the meta-study of Castellacci and Lie (2015). They found that $R \& D$ tax credits have stronger benefits for companies with low R\&D intensity than for highly R\&D intensive companies. As the present sample is restricted to patenting entities, the effect of R\&D subsidies are expected to be weaker than if the sample mainly consisted of catching up of firms lagging behind the technological frontier. In addition, there could be a spurious negative correlation blurring the result, since countries with low R\&D investments may be more likely than other countries to introduce high $R \& D$ tax subsidies to increase $R \& D$ investments. In a similar way, $R \& D$ tax subsidies abroad may lead to higher R\&D investments abroad at the expense of $R \& D$ investments at home, but higher R\&D investments abroad could also have positive spillovers on R\&D investments at home.

\section{2. “Patent shifting” versus shifting of real $R \& D$ activities}

41. MNE groups may locate R\&D investment separately from patent ownership. Indeed, the share of patents that have been shifted, i.e. patents where the inventor is located in a different country than the MNE entity applying for the patent protection, varies significantly across countries (Figure 2). Still, this can reflect factors other than taxes, such as outsourcing of R\&D activities. As discussed above, MNEs may want to concentrate patents at the headquarter level, while the real $R \& D$ activities takes place in $R \& D$ plants in locations with a large supply of high quality researchers.

Figure 2. Share of patents invented in another country

Panel A: Shifted and non-shifted patents as \% of worldwide patents, $1998-2011^{1}$

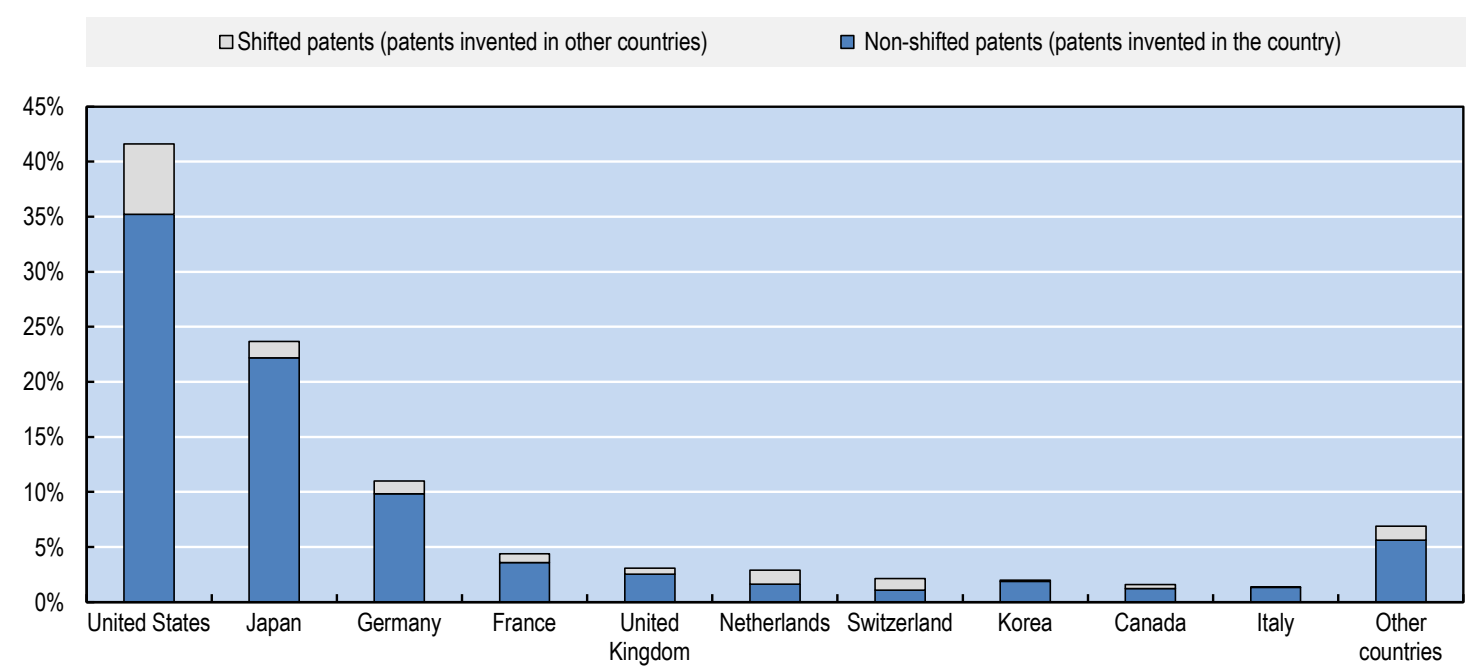


Panel B: Shifted patents as $\%$ of total patents in each country, $1998-2011^{2}$

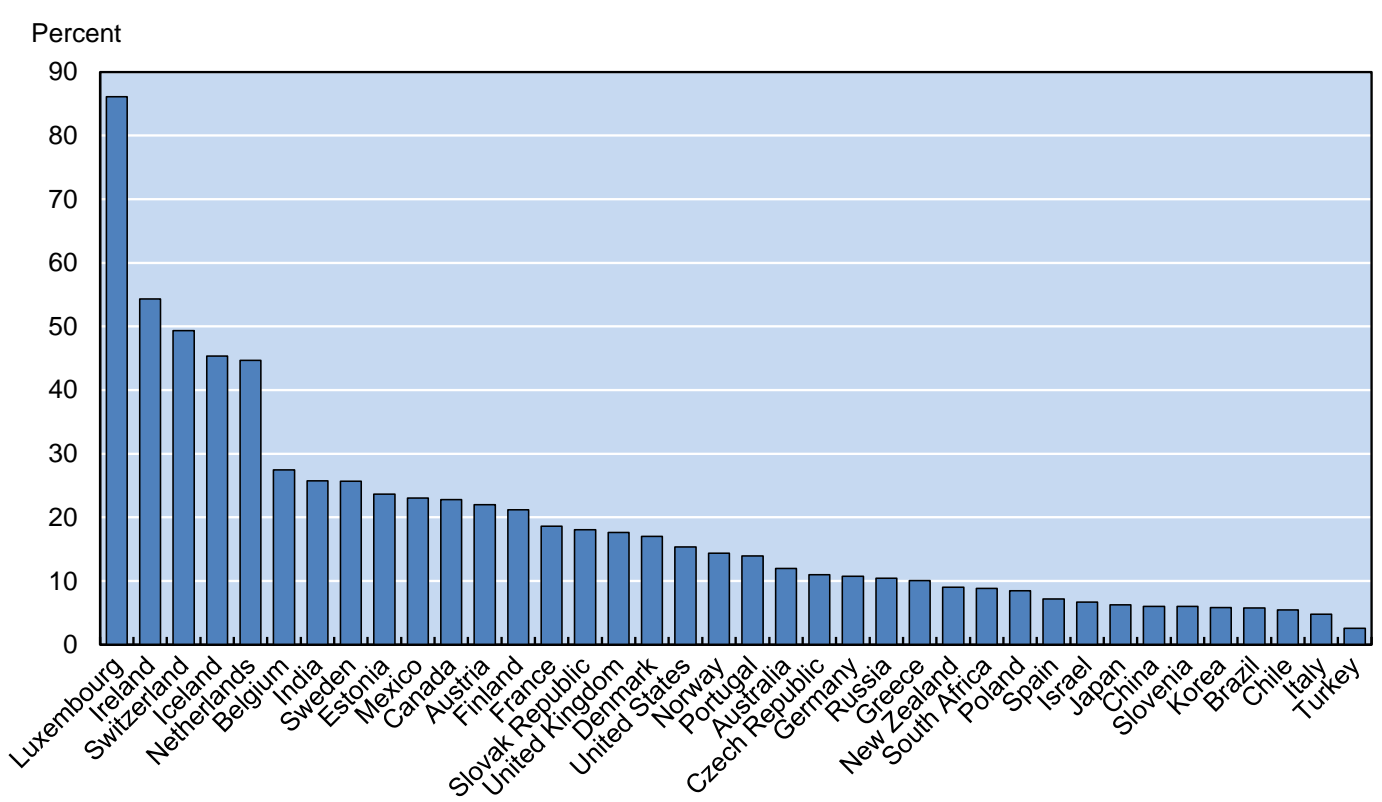

1. Shifted (non-shifted) patents are patents where the inventor is located in a different (the same) country than the MNE entity applying for the patent protection. For example, the United States accounts for $42 \%$ of global patent applications, out of which $35 \%$ are invented in the country and $7 \%$ are invented in another country. Worldwide patent applications refer to the sum of patent applications (shifted and non-shifted) made by the 38 countries included in the analysis (see Panel B). Patent applications refer to applications to two major patent offices (i.e. the United States Patent and Trademark Office (USTPO) and the European Patent Office (EPO)) and patents filed under the Patent Co-Operation Treaty (PCT).

2. For example, in about $85 \%$ of patent applications in Luxembourg, the inventor is located outside Luxembourg.

Source: PATSTAT Database.

42. Restricting the sample to non-shifted patents amounts to isolating the effect of taxes on the location of real R\&D activities. The coefficients on the effective tax rate are found to be negative and of the same magnitude as for the whole sample (Table 4, columns 3-4). Restricting the sample to shifted patents indicates that (as expected) their location is sensitive to taxes and especially preferential regimes (Table 4, columns 5-6).

43. Comparing the results for shifted and non-shifted patents suggests that preferential regimes attract research activities and, with a significantly (four times) higher tax-sensitivity, the ownership of patents invented in other countries. For instance, a 5 percentage point cut in the preferential tax rate on patent income is associated with a $4 \%$ increase in the number of non-shifted patents and a $17 \%$ in the number of shifted patents. In most countries, the number of non-shifted patents in greater than the number of shifted patents, which means that in absolute terms the increase in the number of non-shifted patents can be greater than the increase in shifted patents (Figure 3). For an average country, non-shifted patents would account for two-thirds of the total increase and shifted patents for one third. However, the relative importance of these two effects is likely to vary with the design of the preferential tax treatment, such as activity requirements. The analysis does not distinguish between preferential regimes with or without requirements on the location of research activity. 
Figure 3. Corporate taxes influence the location of non-shifted patents ${ }^{1}$

Change in patent applications induced by a 5 percentage point cut in the preferential tax rate on patent income

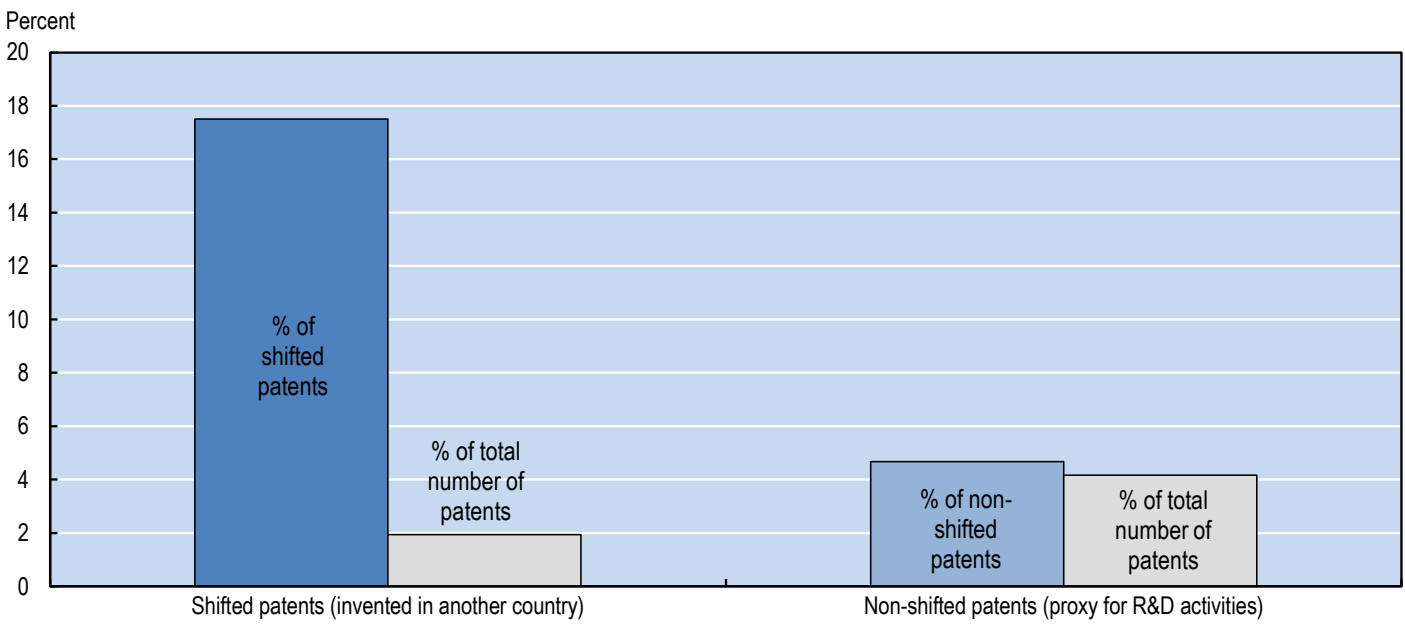

1. Shifted (non-shifted) patents are patents where the inventor is located in a different (the same) country than the MNE entity applying for the patent protection. A 5 percentage point cut in the preferential tax rate on patent income is associated with an increase of $17 \%$ in the number of shifted patents, which corresponds to $2 \%$ of all (shifted and non-shifted) patents. The effect is evaluated for an average country where the share of shifted patents is $11 \%$ (weighted average of available countries).

\subsection{Robustness checks}

44. The results are robust to several robustness checks. Running the regression on certain subsamples (e.g. only manufacturing entities, only European entities) does not change the results. The results are also unaffected when dropping more or less than the upper $0.5 \%$ of the distribution of patenting entities. As discussed, a common alternative to the negative binominal regression model is to estimate a standard OLSregression on the transformed variable $\log (1+$ patents $)$ This is done as a robustness check and the results (Appendix A) are in line with the results of the negative binominal regression model presented in table 4.

\subsection{Effect of anti-avoidance rules}

45. Anti-avoidance rules (i.e. transfer pricing rules and withholding taxes) are expected to have an effect on patent applications. The idea is that for a given number of patents developed in a high-tax country, more patents will be shifted out of the country if it has less strict anti-avoidance rules. As a result, a MNE located in a high-tax country with strong anti-avoidance rules is expected to have a higher number of non-shifted patents than a similar MNE in a country with weaker rules. 
Table 5. Location of patent applications: Anti-avoidance

\begin{tabular}{|c|c|c|c|c|c|c|}
\hline & (1) & (2) & (3) & (4) & (5) & (6) \\
\hline Dependent variable & \multicolumn{2}{|c|}{ All patents } & \multicolumn{2}{|c|}{ Non-shifted patents } & \multicolumn{2}{|c|}{ Shifted patents } \\
\hline Size dummies & Yes & yes & yes & yes & yes & yes \\
\hline Sector dummies & Yes & yes & yes & yes & yes & yes \\
\hline Country dummies & Yes & yes & yes & yes & yes & yes \\
\hline Year dummies & Yes & yes & yes & yes & yes & yes \\
\hline Difference to average effective tax rate on patent income in the group, when & $-1.123^{\star \star *}$ & $-3.046^{\star \star *}$ & $-0.990^{* \star *}$ & $-3.255^{\star \star \star}$ & -0.333 & -1.397 \\
\hline difference is positive & [0.326] & [0.778] & [0.336] & [0.889] & [0.728] & [1.497] \\
\hline Difference to average effective tax rate on patent income in the group, when & $-0.691^{* *}$ & -0.417 & $-0.646^{\star}$ & -0.323 & $-1.885^{\star * *}$ & $-1.730^{* * *}$ \\
\hline $\begin{array}{l}\text { difference is negative } \\
\text { Difference to average effective tax rate on patent income in the group, when }\end{array}$ & [0.322] & $0.776^{* \star *}$ & {$[0.355]$} & $\begin{array}{l}{[0.383]} \\
0.910^{\star \star \star}\end{array}$ & [0.611] & $\begin{array}{l}{[0.608]} \\
0.440\end{array}$ \\
\hline difference is positive interacted with anti-avoidance indicator & & [0.290] & & [0.323] & & {$[0.671]$} \\
\hline Difference to average statutory tax rate in the group & $\begin{array}{c}-0.553^{*} \\
{[0.289]}\end{array}$ & $\begin{array}{c}-0.632^{*} \\
{[0.335]}\end{array}$ & $\begin{array}{l}-0.653^{* *} \\
{[0.298]}\end{array}$ & $\begin{array}{c}-0.649^{*} \\
{[0.333]}\end{array}$ & $\begin{array}{l}0.226 \\
{[0.578]}\end{array}$ & $\begin{array}{c}-1.218^{*} \\
{[0.671]}\end{array}$ \\
\hline Lagged depreciated stock of patent applications (all patents) & $\begin{array}{l}0.011^{\star * *} \\
{[0.001]}\end{array}$ & $\begin{array}{c}0.011^{* * *} \\
{[0.001]}\end{array}$ & & & & \\
\hline Lagged depreciated stock of patent applications (non-shifted) & & & $\begin{array}{l}0.013^{* * *} \\
{[0.001]}\end{array}$ & $\begin{array}{l}0.013^{* * *} \\
{[0.001]}\end{array}$ & & \\
\hline Lagged depreciated stock of patent applications (shifted) & & & & & $\begin{array}{l}0.078^{\star \star *} \\
{[0.006]}\end{array}$ & $\begin{array}{l}0.078^{* *} \\
{[0.006]}\end{array}$ \\
\hline $\begin{array}{l}\text { Difference to average concentration of researchers of countries represented in the } \\
\text { group }\end{array}$ & $\begin{array}{c}0.039^{* * *} \\
{[0.006]}\end{array}$ & $\begin{array}{c}0.037^{* * *} \\
{[0.006]}\end{array}$ & $\begin{array}{c}0.031^{* * *} \\
{[0.006]}\end{array}$ & $\begin{array}{c}0.029^{\star * *} \\
{[0.006]}\end{array}$ & $\begin{array}{c}0.100^{\star \star \star} \\
{[0.017]}\end{array}$ & $\begin{array}{c}0.099^{\star * *} \\
{[0.017]}\end{array}$ \\
\hline Headquarter dummy & $\begin{array}{c}0.295^{\star \star \star} \\
{[0.031]}\end{array}$ & $\begin{array}{c}0.301^{\star * *} \\
{[0.031]}\end{array}$ & $\begin{array}{c}0.273^{\star * *} \\
{[0.031]}\end{array}$ & $\begin{array}{c}0.279^{\star \star \star} \\
{[0.031]}\end{array}$ & $\begin{array}{c}0.568^{\star \star \star *} \\
{[0.067]}\end{array}$ & $\begin{array}{c}0.570^{\star * *} \\
{[0.068]}\end{array}$ \\
\hline Parent dummy & $\begin{array}{c}0.182^{\star * *} \\
{[0.021]}\end{array}$ & $\begin{array}{c}0.181^{* * *} \\
{[0.022]}\end{array}$ & $\begin{array}{c}0.169^{* * *} \\
{[0.021]}\end{array}$ & $\begin{array}{c}0.169^{\star * *} \\
{[0.021]}\end{array}$ & $\begin{array}{c}0.263^{\star \star \star} \\
{[0.044]}\end{array}$ & $\begin{array}{c}0.261^{* * *} \\
{[0.044]}\end{array}$ \\
\hline Number of countries in the group & $0.008^{\star * \star}$ & $0.008^{\star \star *}$ & $0.007^{\star \star \star *}$ & $0.007^{\star \star \star}$ & $0.009^{\star \star \star}$ & $0.009^{* \star \star}$ \\
\hline Lagged RD tax subsidies at home & $\begin{array}{c}{[0.001]} \\
-0.102\end{array}$ & $\begin{array}{c}{[0.001]} \\
-0.172\end{array}$ & $\begin{array}{c}{[0.000]} \\
-0.083\end{array}$ & $\begin{array}{c}{[0.001]} \\
-0.161\end{array}$ & $\begin{array}{l}{[0.001]} \\
0.197\end{array}$ & $\begin{array}{l}{[0.001]} \\
0.142\end{array}$ \\
\hline 1 aged average $R$ tay cuhcidiec in the aroun & $\begin{array}{l}{[0.308]} \\
0.081\end{array}$ & $\begin{array}{l}{[0.320]} \\
0.070\end{array}$ & $\begin{array}{l}{[0.327]} \\
0.164\end{array}$ & $\begin{array}{l}{[0.338]} \\
0.152\end{array}$ & $\begin{array}{c}{[0.395]} \\
-0.917^{\star \star *}\end{array}$ & $\begin{array}{c}{[0.406]} \\
-0.924^{\star \star \star}\end{array}$ \\
\hline Lagged average $\mathrm{R} \mathrm{U}$ tax subsidies in the group & {$[0.110]$} & {$[0.110]$} & {$[0.115]$} & {$[0.115]$} & {$[0.216]$} & [0.218] \\
\hline Observations & 93,759 & 93,720 & 93,759 & 93,720 & 93,759 & 93,720 \\
\hline
\end{tabular}


46. The effect of anti-avoidance rules (i.e. transfer pricing rules and withholding taxes) on patent applications is presented in Table 5. The regression results suggest that this effect is at play, since the coefficient of the interacted term for non-shifted patents is positive and significant. This suggests that stronger anti-avoidance rules are associated with higher patent numbers in high-tax countries, which may indicate that fewer patents are shifted out of the country. Increasing the anti-avoidance classification with one unit (on a 0-4 scale) is associated, for a firm that has a 5 percentage points higher effective tax rate on patent income than the average of the group, with an increase in the number of patent applications by 4.7 percent. As expected, there is no significant effect of anti-avoidance rules on the number of shifted patents. This is because the shifted patens are patents invented abroad and shifted to country c, and the antiavoidance rules of country $\mathrm{c}$ is designed to reduce shifting away from country $\mathrm{c}$, not designed to reduce shifting to country $\mathrm{c}$.

\section{Conclusion}

47. This paper estimates the effect of taxes on MNEs' choice of patent location, based on a large sample of patents from the OECD-PATSTAT merged with data on firm characteristics from the OECDORBIS databases over 2004-10. The study distinguishes between non-shifted patents, which are patents where the country of the applicant is the same as the country of the inventor, and shifted patents, where the country of inventor and applicant differ.

48. Corporate taxes are found to influence the location of research activities and the legal ownership of patents. Preferential intellectual property regimes attract research activities and, the ownership of patents invented in other countries. For instance, a 5 percentage point cut in the preferential tax rate on patent income is associated with a $6 \%$ increase in patent applications. On average, about two-thirds of the increase comes from patents invented at home and one third from patents invented abroad, but the relative importance of these two effects is likely to vary with the design of the preferential regime and especially the existence of activity requirements.

49. The analysis also suggests that anti-avoidance rules against tax planning can reduce the potential for tax-motivated patent shifting. Indeed, in higher-tax rate countries, strict anti-avoidance rules are associated with higher numbers of non-shifted patents, which suggests that fewer patents may be shifted out than in similar countries with less strict rules. 


\section{REFERENCES}

Akcigit U., S. Baslandze and S. Stantcheva (2015), "Taxation and the International Mobility of Inventors", NBER Working Paper, No. 21024, National Bureau of Economic Research.

http://www.nber.org/papers/w21024

Alstadsæter, A, S. Barrios, G. Nicodème, A.M. Skonieczna and A. Vezzani (2015), "Patent Boxes Design, Patents Location and Local R\&D", CEPR Discussion Paper, No. 10679, Centre for Economic Policy Research.

http://www.cepr.org/active/publications/discussion_papers/dp.php?dpno=10679\#

Andrews, D., C. Criscuolo and C. Menon (2014), "Do Resources Flow to Patenting Firms?: Cross-Country Evidence from Firm Level Data", OECD Economics Department Working Papers, No. 1127, OECD Publishing.

http://dx.doi.org/10.1787/5jz2lpmk0gs6-en

Arnold, J., B. Brys, C. Heady, A. Johansson, C. Schwellnus and L. Vartia (2011), "Tax Policy for Economic Recovery and Growth”, Economic Journal, Royal Economic Society, Vol. 121.

Blomström, M. and A Kokko (1998), "Multinational corporations and spillovers", Journal of Economic Surveys, 12 (3), 247-277. http://dx.doi.org/10.1111/1467-6419.00056

Blundell, R., R Griffith and J. Van Reenen (1995), "Dynamic Count Data Models of Technological Innovation", The Economic Journal, 105 (429), 333-344.

http://www.jstor.org/stable/2235494

Böhm T., T. Karkinsky and N. Riedel (2012), "The Impact of Corporate Taxes on R\&D and Patent Holdings", mimeo.

http://www.sbs.ox.ac.uk/sites/default/files/Business_Taxation/Events/conferences/2012/tapes/bohmkarkinsky-riedel.pdf

Buettner, T., M. Overesch, U. Schreiber and G. Wamser (2012), "The impact of thin-capitalization rules on the capital structure of multinational firms", Journal of Public Economics, 96 (11-12), 930-938. http://dx.doi.org/10.1016/j.jpubeco.2012.06.008

Cameron A.C and P.K. Trivedi (2013), Regression Analysis of Count Data (2 ${ }^{\text {nd }}$ Edition), Cambridge University Press

Castellacci, F. and C.M. Lie (2015), "Do the effects of R\&D tax credits vary across industries? A metaregression analysis", Research Policy, 44 (8), 819-832.

http://dx.doi.org/10.1016/j.respol.2015.01.010

CPB Netherlands Bureau for Economic Policy Analysis (2014), "A Study on R\&D Tax Incentives. Final Report", European Commission Taxation Paper, No. 52, European Commission.

http://ec.europa.eu/taxation_customs/resources/documents/taxation/gen_info/economic_analysis/tax papers/taxation paper 52.pdf

Criscuolo, C., D. Czarnitzki, C. Hambro and J. Warda (2009), "Design and Evaluation of Tax Incentives for Business Research and Development: Good Practice and Future Development", final report 
submitted by the Expert Group on Impacts of R\&D Tax Incentives to the European Commission, Directorate General - Research, 15 November.

http://ec.europa.eu/invest-in-research/pdf/download_en/tax_expert_group_final_report_2009.pdf

Dharmapala, D. (2014), "What do we know about base erosion and profit shifting? A review of the empirical literature", Fiscal Studies, 35 (4), 421-448.

http://dx.doi.org/10.1111/j.1475-5890.2014.12037.x/pdf

Dischinger, M. and N. Riedel (2011), "Corporate taxes and the location of intangible assets within multinational firms", Journal of Public Economics, 95 (7-8), 691-707.

http://dx.doi.org/10.1016/j.jpubeco.2010.12.002

Ernst, C., K. Richter and N. Riedel (2014): Corporate taxation and the quality of research and development, International Tax and Public Finance, 21 (4), 1-26. http://dx.doi.org/10.1007/s10797-014-9315-2

Ernst, C. and C. Spengel (2011), "Taxation, R\&D Tax Incentives and Patent Application in Europe", ZEW Discussion Paper, 11-024, Centre for European Economic Research - ZEW Mannheim. ftp://ftp.zew.de/pub/zew-docs/dp/dp11024.pdf

Evers, L., H. Miller and C. Spengel (2014), "Intellectual Property Box Regimes: Effective Tax Rates and Tax Policy Considerations", International Tax and Public Finance, 22 (3), 502-530. http://dx.doi.org/10.1007/s10797-014-9328-x

Greene, W.H. (2003), Econometric Analysis (5 ${ }^{\text {th }}$ Edition), Prentice Hall

Griffith, R., H. Miller and M. O'Connell (2014), "Ownership of intellectual property and corporate taxation", Journal of Public Economics, 112, 12-23. http://dx.doi.org/10.1016/j.jpubeco.2014.01.009

Grubert, H. (2003), "Intangible Income, Intercompany Transactions, Income Shifting, and the Choice of Location", National Tax Journal, 56 (1), 221-242. http://www.jstor.org/stable/41789665

Hall, B. and J. Van Reenen, (2000). "How Effective Are Fiscal Incentives for R\&D? A Review of the Evidence“, Research Policy, 29 (4-5), 449-469. http://dx.doi.org/10.1016/S0048-7333(99)00085-2

Huizinga, H. and L. Laeven (2008), "International profit shifting within multinationals: a multi-country perspective",\%20Journal\%20of\%20Public\%20Economics,\%2092\%20(5-6),\%2011641182.\%20http:/dx.doi.org/10.1016/j.jpubeco.2007.11.002

Johansson Å., Skeie Ø., S. Sorbe and C. Menon (2016a), "Tax planning by multinational firms: firm-level evidence from a cross-country database", OECD Economics Department Working Papers No. 1355, OECD Publishing.

Johansson $\AA$., Skeie Ø. and S. Sorbe (2016b), “Anti-avoidance rules against international tax planning: a classification”, OECD Economics Department Working Papers No. 1356, OECD Publishing.

Karkinsky, T. and N. Riedel (2012), "Corporate taxation and the choice of patent location within multinational firms", Journal of International Economics, 88 (1), 176-185. http://dx.doi.org/10.1016/j.jinteco.2012.04.002 
Mairesse, J. and P. Mohnen, (2010), "Using innovation surveys for econometric analysis" in Hall, B.H., Rosenberg, N. (Eds.), Handbook of the Economics of Innovation Volume 2. Elsevier, Amsterdam, $1129-1155$.

http://dx.doi.org/10.1016/S0169-7218(10)02010-1

Menon, C. (2016), “An algorithm to identify multinational groups in ORBIS”, forthcoming.

OECD (2010), 2010 Report on the Attribution of Profits to Permanent Establishments. http://www.oecd.org/ctp/transfer-pricing/45689524.pdf

OECD (2013a), New Sources of Growth: Knowledge-Based Capital Key Analyses and Policy Conclusions, OECD Publishing.

http://www.oecd.org/sti/inno/knowledge-based-capital-synthesis.pdf

OECD (2013b), Action Plan on Base Erosion and Profit Shifting, OECD Publishing. http://www.oecd.org/ctp/BEPSActionPlan.pdf

OECD (2015a), OECD Innovation Strategy, DSTI/IND/STP/ICCP(2015)1-5.

OECD (2015b), BEPS Action 11, Annex A: Economic Implications of Multinational Tax Planning, OECD/G20 Base Erosion and Profit Shifting Project, OECD Publishing.

Overesch, M. and G. Wamser (2014), "Bilateral internal debt financing and tax planning of multinational firms", Review of Quantitative Finance and Accounting, 42 (2), 191-209. http://dx.doi.org/10.1007/s11156-012-0339-3

Pinto Ribeiro, S., S. Menghinello and K. D. Backer (2010), "The OECD ORBIS Database: Responding to the Need for Firm-Level Micro-Data in the OECD", OECD Statistics Working Papers, No. 2010/01, OECD Publishing. http://dx.doi.org/10.1787/5kmhds8mzj8w-en

PWC (2013), Global Research and Development Incentives Group, November 2013. http://www.pwc.com/gx/en/tax/assets/pwc-global-r-and-d-incentives-brochure-nov-2013.pdf

Ragoussis, A. and E. Gonnard (2012), "The OECD-ORBIS Database - Treatment and Benchmarking Procedures", OECD mimeo.

Silberztein, C. (2011), Transfer pricing aspects of intangibles: the OECD project, Transfer Pricing International Journal, 08/11, 1-6. http://www.oecd.org/tax/transfer-pricing/48594010.pdf

Sorbe S. and Å. Johansson (2016), "International tax planning and fixed investment", OECD Economics Department Working Papers No. 1361, OECD Publishing.

Sorbe S., Johansson $\AA$., and Ø., Skeie (2016), "Debt and tax planning by multinationals", OECD Economics Department Working Papers No. 1357, OECD Publishing.

Squicciarini, M. and H. Dernis (2013), "A Cross-Country Characterisation of the Patenting Behaviour of Firms based on Matched Firm and Patent Data", OECD Science, Technology and Industry Working Papers, No. 2013/05, OECD Publishing.

http://dx.doi.org/10.1787/5k40gxd4vh41-en 
Warda, J. (2001), "Measuring the Value of R\&D Tax Treatment in OECD Countries", STI Review, No.27: Special Issue on New Science and Technology Indicators, OECD Publishing.

http://www.oecd.org/sti/37124998.pdf

Westmore, B. (2013)," R\&D, Patenting and Growth. The Role of Public Policy", OECD Economics Department Working Papers, No. 1047, OECD Publishing.

http://dx.doi.org/10.1787/5k46h2rfb4f3-en

Wooldridge, J.M. (2010), Econometric Analysis of Cross Section and Panel ( $2^{\text {nd }}$ Edition), MIT Press. 
APPENDIX A: LOCATION OF PATENT APPLICATIONS: OLS-SPECIFICATION

\begin{tabular}{|c|c|c|c|c|c|c|}
\hline & (1) & $(2)$ & (3) & (4) & (5) & (6) \\
\hline Dependent variable & \multicolumn{2}{|c|}{ All patents } & \multicolumn{2}{|c|}{ Non-shifted patents } & \multicolumn{2}{|c|}{ Shifted patents } \\
\hline Size dummies & yes & yes & yes & yes & yes & yes \\
\hline Sector dummies & yes & yes & yes & yes & yes & yes \\
\hline Country dummies & yes & yes & yes & yes & yes & yes \\
\hline Year dummies & yes & yes & yes & yes & yes & yes \\
\hline Difference to average effective tax rate on natent income in the aroun & $-0.465^{\star \star \star}$ & & $-0.376^{\star \star \star}$ & & -0.082 & \\
\hline Enterence to average enective lax rate on palent mcome in me group & [0.108] & & [0.099] & & {$[0.056]$} & \\
\hline $\begin{array}{l}\text { Difference to average effective tax rate on patent income in the group, when no } \\
\text { patent box at home }\end{array}$ & & $\begin{array}{r}-0.313^{*} \\
{[0.168]}\end{array}$ & & $\begin{array}{l}-0.321^{* *} \\
{[0.158]}\end{array}$ & & $\begin{array}{l}0.088 \\
{[0.082]}\end{array}$ \\
\hline $\begin{array}{l}\text { Difference to average effective tax rate on patent income in the group, when patent } \\
\text { box at home }\end{array}$ & & $\begin{array}{l}-0.677^{* * *} \\
{[0.132]}\end{array}$ & & $\begin{array}{l}-0.454^{* * *} \\
{[0.111]}\end{array}$ & & $\begin{array}{l}-0.319^{* * *} \\
{[0.069]}\end{array}$ \\
\hline Difference to average statutory tax rate in the group & -0.171 & $-0.295^{*}$ & $-0.196^{*}$ & $-0.242^{*}$ & -0.078 & $-0.216^{\star \star \star}$ \\
\hline Lagged depreciated stock of patent applications (all patents) & $\begin{array}{c}{[0.122]} \\
0.004^{\star * *} \\
{[0.000]}\end{array}$ & $\begin{array}{c}{[0.154]} \\
0.004^{\star * *} \\
{[0.000]}\end{array}$ & [0.115] & [0.144] & [0.062] & [0.075] \\
\hline Lagged depreciated stock of patent applications (non-shifted) & & & $\begin{array}{c}0.005^{\star * *} \\
{[0.000]}\end{array}$ & $\begin{array}{l}0.005^{\star \star \star} \\
{[0.000]}\end{array}$ & & \\
\hline Lagged depreciated stock of patent applications (shifted) & & & & & $\begin{array}{l}0.007^{* * *} \\
{[0.001]}\end{array}$ & $\begin{array}{l}0.007^{* * *} \\
{[0.001]}\end{array}$ \\
\hline $\begin{array}{l}\text { Difference to average concentration of researchers of countries represented in the } \\
\text { group }\end{array}$ & $\begin{array}{c}0.019^{* * *} \\
{[0.003]}\end{array}$ & $\begin{array}{l}0.019^{* * *} \\
{[0.003]}\end{array}$ & $\begin{array}{l}0.015^{\star * *} \\
{[0.002]}\end{array}$ & $\begin{array}{l}0.015^{\star * *} \\
{[0.002]}\end{array}$ & $\begin{array}{c}0.012^{\star \star \star} \\
{[0.002]}\end{array}$ & $\begin{array}{c}0.012^{\star * *} \\
{[0.002]}\end{array}$ \\
\hline Headquarter dummy & $\begin{array}{c}0.173^{\star * *} \\
{[0.021]}\end{array}$ & $\begin{array}{c}0.174^{\star * *} \\
{[0.021]}\end{array}$ & $\begin{array}{c}0.153^{\star * \star} \\
{[0.020]}\end{array}$ & $\begin{array}{c}0.154^{\star \star \star} \\
{[0.020]}\end{array}$ & $\begin{array}{c}0.068^{\star * \star} \\
{[0.009]}\end{array}$ & $\begin{array}{c}0.069 * * * \\
{[0.009]}\end{array}$ \\
\hline Parent dummy & $\begin{array}{c}0.065^{\star \star *} \\
{[0.010]}\end{array}$ & $\begin{array}{c}0.065^{\star * \star} \\
{[0.010]}\end{array}$ & $\begin{array}{c}0.057^{\star \star *} \\
{[0.009]}\end{array}$ & $\begin{array}{c}0.057^{\star * \star} \\
{[0.009]}\end{array}$ & $\begin{array}{c}0.018^{\star \star \star} \\
{[0.004]}\end{array}$ & $\begin{array}{c}0.018^{\star * *} \\
{[0.004]}\end{array}$ \\
\hline Number of countries in the aroup & $0.003^{* * *}$ & $0.003^{* * *}$ & $0.002^{* \star *}$ & $0.002^{\star \star \star}$ & $0.002^{\star \star \star}$ & $0.002^{* \star *}$ \\
\hline TNumider or coumtries in the group & $\begin{array}{l}{[0.000]} \\
0.083\end{array}$ & $\begin{array}{l}{[0.000]} \\
0.127\end{array}$ & $\begin{array}{l}{[0.000]} \\
0.046\end{array}$ & $\begin{array}{l}{[0.000]} \\
0.062\end{array}$ & $\begin{array}{c}{[0.000]} \\
0.069^{\star \star}\end{array}$ & $\begin{array}{c}{[0.000]} \\
0.119^{\star \star \star}\end{array}$ \\
\hline Lagged RD tax subsidies at home & {$[0.116]$} & {$[0.121]$} & {$[0.119]$} & {$[0.122]$} & {$[0.031]$} & {$[0.035]$} \\
\hline Lagged average RD tax subsidies in the group & $\begin{array}{c}-0.004 \\
{[0.042]}\end{array}$ & $\begin{array}{l}-0.012 \\
{[0.044]}\end{array}$ & $\begin{array}{l}-0.007 \\
{[0.042]}\end{array}$ & $\begin{array}{l}-0.010 \\
{[0.043]}\end{array}$ & $\begin{array}{c}-0.030^{* *} \\
{[0.015]}\end{array}$ & $\begin{array}{c}-0.038^{* *} \\
{[0.016]}\end{array}$ \\
\hline Observations & 93,759 & 93,759 & 93,759 & 93,759 & 93,759 & 93,759 \\
\hline R-squared & 0.400 & 0.400 & 0.410 & 0.410 & 0.285 & 0.285 \\
\hline
\end{tabular}

